\title{
Secondary School Teachers' Perceptions for the Concepts of Compassion and Bullying
}

\author{
Fatih AYDEMIR ${ }^{1}$, Ahmet GÖÇEN², and İbrahim YILDIRIM ${ }^{3}$ \\ ${ }^{1,2}$ Harran University, Turkey. \\ ${ }^{3}$ Gaziantep University, Turkey
}

\begin{abstract}
Compassion, sparked by the conscience, is the acts towards the helplessness and includes the effort to resolve the neediness. Bullying is the act of violence of all sorts, which the one in power does continuously and intentionally to the weaker. In this study, the opinions of the teachers about these two opposing concepts were examined using qualitative research methods. For this purpose, teachers were asked questions about their perceptions of the concepts of bullying and compassion, the examples they observed about these concepts and their views on the relationship between these two concepts. Teachers' answers were analysed by content analysis. According to this, it can be said that teachers perceive the concepts of bullying and compassion as two poles of a magnet. This study presented a different perspective on bullying and mobbing in schools.
\end{abstract}

Keywords: bullying, compassion, teachers' perceptions.

\section{Introduction}

The purpose of this study, in which the concepts of compassion and bullying are questioned with teachers, is to determine the perceptions of teachers regarding these two concepts. It is thought that this research will contribute to the literature by revealing the existence and status of a relationship between bullying and compassion, which is not much researched. In addition, it can be said that the study will bring a different perspective in the solution of bullying situations based on the opinions of the teachers

\section{Methodology}

This research aims to reveal the meanings attributed to the concepts of compassion and bullying by teachers. For this reason, the research was designed according to phenomenological research, one of the qualitative research methods. Qualitative research is preferred when a 


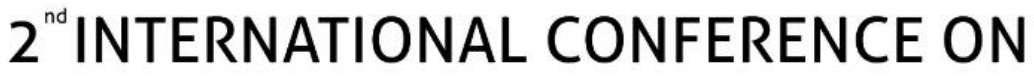 FUTURE OF TEACHING \& EDUCATION}

\section{Munich,Germany}

\section{6 - 8 December,2019}

problem or subject is desired to be discovered (Creswell, 2009). Research that involves revealing the ideas and implications of a person on phenomena or facts is called phenomenological research (Yıldırım \& Şimşek, 2008). For the research, questions about teachers' perceptions on both concepts were prepared by taking the opinions of three experts in the field of educational sciences. The questions in semi structured form were sent to the teachers in Turkey's South-eastern region with the help of Google Forms and answered in detail.

For credibility, it was controlled and checked by an academician who was qualified in qualitative research in the stages of data collection, coding, tabulation and reporting. In addition, the researcher stated his preliminary assumptions on the subject. The theory triangulation method was preferred by the researcher about dependability. Thus, the consistency of the data obtained in similar studies in the literature was examined in detail. For the confirmability, the raw data and analysed forms were retained. The study process, purpose and methods were clearly stated. Regarding transferability, the participants and the environment were explained in detailed way.

\section{Conclusion and Discussion}

According to the results of the study, the majority of the teachers said that compassion was directed towards all living things (Koç, 2015), while bullying was only directed at people (Y1ldırım, 2008).

Bullying in the eyes of the teachers in the research is a condition that includes psychological and physical violence, undesirable behaviour and abuse, provided that there is an imbalance of power to the individual. According to the teachers' mental schemes, a behaviour must meet certain conditions in order to be considered as bullying. These are power imbalance, pleasure and continuity according to their weight. Y1ldirım (2012) states that in order for a behaviour to be considered bullying, it must meet the conditions of power imbalance, intent and continuity.

According to teachers' perceptions, behaviours related to compassion in school are more than bullying behaviours. Teachers in this study think that compassion as more of a feeling. They call this feeling the most as pity and affection. At a minimum, it is perceived as an act. Compassion is described in the literature as the meeting the needs of a person in need with a feeling of pity (Gazali, 1975).

Teachers were found to observe mostly physical violence in bullying cases among students. As for compassion, teachers were mainly faced with helping the needy and moral support among the students. According to the perceptions of the teacher, the concepts of bullying and compassion are opposite to each other like the two poles of the magnet.

About the study implications, it can be said that studies can be done to reduce compulsion and bullying in schools by placing specific programs that considers the opinions of teachers in the study. It can be thought that these studies will have a positive effect on decreasing bullying and 


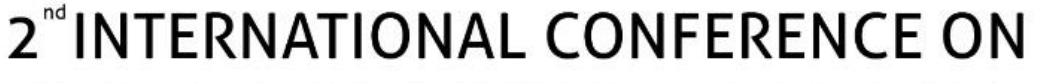 FUTURE OF TEACHING \& EDUCATION}

\section{Munich,Germany}

\section{6 - 8 December,2019}

mobbing behaviours. It can be said school wide programs and studies with the voluntary participation of teachers and students will increase the positive effect.

\section{References}

[1] Creswell, J. W. (2009). Research design: Qualitative, quantitative, and mixed methods approaches (3rd ed.). Thousand Oaks, CA: Sage.

[2] Gazali (1975). Kimya-yı Saadet, Çev. A. Faruk Meyan, Bedir Publications, İstanbul.

[3] Koç, Z. H. (2015). Vicdanın ahlâkî ve teolojik temelleri. Unpublished master thesis, Ankara University.

[4] Yıldırım, A., \& Şimşek, H. (2008). Sosyal bilimlerde nitel araştırma yöntemleri (7th ed.). Seçkin Publications.

[5] Yıldırım, R. (2012). Akran zorbalığı. Celal Bayar Üniversitesi Sosyal Bilimler Dergisi, $10(2)$.

[6] Yıldırım, T. (2008). İlköğretim okullarında öğretmen-yönetici ilişkilerinde yıldırma ve etkileri. Unpublished master thesis. Yeditepe University, İstanbul. 